\title{
MENCEGAH TINDAK KEKERASAN DAN TAWURAN ANTAR PELAJAR MELALUI PENGEMBANGAN PROGRAM PELATIHAN SOCIAL PERSPECTIVE TAKING DI SEKOLAH
}

\author{
Nanik Yuliati \\ Dosen pada Jurusan Ilmu Pendidikan FKIP Universitas Jember \\ Email: nanikyuliati@gmail.com
}

\begin{abstract}
Abstrak
Tulisan ini menyampaikan gagasan konseptual tentang pendekatan intervensi psikologis untuk mencegah tindak kekerasan dan tawuran. Rendahnya kemampuan mengambil perspektif orang lain dalam menyelesaikan masalah dipandang sebagai faktor penyebab. Pendekatan perkembangan dipandang dan dijadikan sebagai pendekatan alternatif guna meranang program yang efektif. Kemampuan mengambil perspektif orang lain bukan merupakan kemampuan bawaan tetapi dapat dipelajari. Pengambilan program pelatihan kemampuan mengambil perspektif orang lain dapat dijadikan perlakuan alternatif. Program ini sebaiknya bersifat preventif dan menjadi bagian dari kurikulum sekolah.
\end{abstract}

Kata kunci: tindak kekerasan pelajar, pencegahan, perspektif taking, pendekatan perkembangan

\section{Abstract}

This writing proposed conceptual idea about psychological interviewing approach preventing violence and fighting. Low of perspective taking in solving problems is viewed as a reason. Developmental approach is considered to be an alternative approach for effective program designed. Perspective taking ability is not inherited but learned. Developmental of perspective taking training program could be an alternative treatment. This program should be preventive and being part of curriculum. .

Keywords: student violence, preventive, perspektif taking, development approach,

\section{PENDAHULUAN}

Maraknya peristiwa tawuran antar pelajar di berbagai kota di Indonesia, khususnya yang dilakukan oleh kaum pelajar di tingkat SMP dan SLA, menjadi fenomena yang sering muncul menjadi berita utama di berbagai media massa. Meskipun tawuran antar pelajar itu sendiri bukan hal yang baru dalam sejarah perkembangan manusia, namun yang terjadi pada beberapa tahun belakangan ini dinilai oleh banyak pihak telah melampaui batas dan berpotensi mengancam rasa aman lingkungan dan kesatuan bangsa. Dikemukakan oleh Kominisi Nasional Perlindungan Anak (Komnas-PA) dalam catatan akhit tahunnya yang diunggah dalam Blog Komnas-PA pada Desember 2011, bahwa kasus kekerasan dan tawuran antar pelajar menjadi fenomena sosial yang banyak mendapat sorotan dan perhatian masyarakat. Oleh karena itu dibutuhkan 
upaya-upaya konkrit yang lebih efektif guna menangani dan mencegahnya.

Gambaran tentang data tawuran pelajar dapat diikuti beritanya di berbagai media masa, alah satunya yang dipandang terbaru dan terpercaya adalah data yang dirilis oleh Komnas PA. Sebagaimana dikemukakan dalam catatan akhir tahunnya yang diunggah dalam Blog Komnas-PA pada Desember 2011, dalam tahun 2011 terjadi 339 kasus tawuran antar pelajar yang menyebabkan 82 orang siswa meninggal dunia dan selebihnya luka berat. Angka tersebut mengalami peningkatan yang cukup signifikan dari tahun sebelumnya yang hanya mencapai 128 kasus. Menurut catatan Komnas PA, sebagian besar pelaku tawuran adalah pelajar tingkat SMP dan SLA. Dalam rilis lanjutan Komnas PA juga mengemukakan data tawuran antar pelajar pada enam bulan pertama tahun 2012, yakni dari bulan Januari hingga bulan Juni. Antara Januari hingga Juni 2012 Komnas PA mencatat sebanyak 139 kasus tawuran di wilayah Jakarta yang menyebabkan 12 pelajar meninggal dunia. Jika data itu dihitung sampai bulan desembar dari seluruh kota yang ada di Indonesia, tentu angkanya akan berlipat ganda. Demikian pula, bila melihat trennya, meskipun belum diperoleh data yang pasti, kasus tindak kekerasan dan tawuran antar pelajar pada tahun 2013 tentu juga meningkat, setidaknya ini bila diperhatikan dari banyaknya tindak kekerasan dan tawuran antar pelajar yang diberitakan di media massa dan belum efektifnya upaya-upaya pencegahan yang dilakukan.

Tidak bisa disangkal bahwa kasus kekerasan dan tawuran antar pelajar menjadi permasalahan yang perlu dipecahkan karena ia tergolong menyimpang dari berbagai norma (norma masyarakat, norma hukum, dan norma perkembangan), merugikan bukan hanya korban tetapi juga pelaku, mengancam rasa aman lingkungan, mengancam kesatuan dan pelestarian bangsa, dan merugikan keluarga dan negara melalui biaya yang harus dikeluarkan untuk menangani berbagai akibat buruk dari tawuran. Tawuran juga berpotensi mengancam kinerja akademik dan keberhasilan hidup pelajar yang terlibat. Keterlibatan dalam berbagai tindak kekerasan dan tawuran menyebabkan pelajar tidak efisien menggunakan energinya untuk kegiatan yang ada hubungannya dengan belajar. Dengan kata lain mereka tidak mengorientasikan dirinya terhadap kegiatan akademik dan pada gilirannya dapat diramalkan prestasi akademik mereka cenderung rendah. Rendahnya prestasi akademik ini tentu menjadi akar dari berbagai permasalahan yang akan muncul kemudian seperti kegagalankegagalan lanjutan, konflik dengan guru dan orang tua, dan berkurangnya peluang karier di masa depan.

Mendidik generasi muda, menjaga rasa aman lingkungan, dan menjaga kesatuan bangsa dapat menjadi tanggung jawab semua pihak, namun lembaga pendidikan sekolah memiliki peran yang sangat penting. Dengan kata lain, berbagai kasus tindak kekerasan dan tawuran antar pelajar memiliki implikasi langsung pada lembaga pendidikan sekolah untuk menemukan dan mengembangkan program-program penanganan dan pencegahan yang lebih efektif. Meningkatnya peristiwa kekerasan dan tawuran antar pelajar menjadi indikator bahwa program-program intervensi yang telah dilakukan terbukti tidak efektif. Bahkan mata pelajaran agama tampak tak memberikan pengaruh yang signifikan.

Tulisan ini akan mengemukakan suatu gagasan konseptual tentang suatu pendekatan yang dipandang potensial guna mencegah tindak kekerasan dan tawuran antar pelajar, yakni suatu pendekatan intervensi yang dirancang berdasarkan pendekatan perkembangan. Sesuai dengan konsepsinya, pendekatan perkembangan mengarahkan intervensinya bukan pada gejalanya tetapi tetapi dengan cara 
memodifikasi faktor-faktor yang menyebabkan terjadinya gejala itu (Lerner \& Hultsch, 1982; Papalia \& Olds, 1995). Jadi, intervensi bersifat tidak langsung. Faktor-faktor tersebut bisa berupa hambatan dalam perkembangan aspek fisik, kognitif, dan sosial. Tulisan ini tidak akan menguraikan hubungan antara tindak kekerasan dan tawuran dengan hambatan semua aspek perkembangan, tatapi hanya akan membatasi pada hambatan perkembangan aspek kognitif. Hambatan kognitif berkaitan dengan hambatan kemampuan berpikir dan melakukan tugastugas pemahaman dan penalaran. Dalam hubungannya dengan konteks sosial atau hubungan antara individu dengan orang lain - hubungan interpersonal atau interaksi sosial - kemampuan kognitif yang memainkan peran penting dalam mempengaruhi kualitas hubungan atau tindakan agresif adalah kemampuan dalam mengambil perspektif orang lain. Dalam literatur psikologi edisi bahasa asing (Inggris), kemampuan ini populer dengan nama perspective taking.

\section{Konsepsi dan Teori tentang Tindak Kekerasan dan Tawuran}

Dalam Kamus Besar Bahasa Indonesia istilah tawuran digunakan untuk menggambarkan suatu peristiwa perkelahian yang dilakukan secara beramai-ramai. Sedangkan tindak kekerasan adalah tindakan yang bertujuan menyerang, melukai, dan membahayakan orang lain. Pengertian ini sepertinya tidak berbeda dengan apa yang digunakan oleh media yang memberiterakan peristiwa perkelahian antar sejumlah orang dengan istilah tawuran. Dalam kehidupan sehariharipun ketika kita mendengar atau menyebut tawuran, yang terlintas di benak kita adalah perkelahian antar kelompok atau yang melibatkan beberapa orang.

Jika dikaji dalam literatur psikologi, berdasarkan pada karakteristik yang inheren di dalam tindak kekerasan dan tawuran, tindak kekerasan dan tawuran merupakan bentuk tindakan agresi (Steinberg, 2002). Banyak ahli psikologi yang mengklasifikasikan gangguan perilaku ke dalam dua arah, gangguan yang dirasakan sendiri (internalize/inward disorder) dan yang dimanifestasikan ke luar (externalized/outward disorder); dan agresi merupakan salah satu bentuk gangguan perilaku yang dimanifestasikan ke luar. Dari beberapa definisi perilaku agresi yang dikaji, misalnya definisi dari Hetherington (1993), Berkowitz (1995), dan Baron (2002) semuanya menegaskan bahwa perilaku agresi merupakan suatu tindakan yang bertujuan untuk menyerang, melukai atau menyakiti, dan mengancam atau membahayakan orang lain. Seperti juga ditegaskan oleh Nicolson dan Ayers (2004) bahwa konsep perilaku agresi merupakan suatu bentuk manifestasi keluar dari permusuhan terhadap orang lain dan keinginan untuk membahayakan orang lain. Agresi yang terjadi pada periode remaja juga sering disebut sebagai gangguan perilaku (conduct disorder).

Menurut Nicolson dan Ayers (2004), demikianpun dari fakta-fakta yang dapat kita amati, remaja dapat melakukan tindakan agresif di dalam konteks keluarga, sekolah, dan masyarakat. Remaja seperti itu senang melanggar aturan, mengambil resiko, melawan otoritas, destruktif, curang, dan kejam. Mereka gampang marah, impulsif, dan seringkali terlibat konflik dengan kelompoknya, orang tua dan guru, mencuri, membolos sekolah, meninggakan (lari dari) rumah, merusak lingkungan, dan sering berurusan dengan hukum dan pihak kemananan. Dikatakan oleh Menurut Nicolson dan Ayers (2004) dan beberapa hasil penelitian yang dilaporkan oleh Steinberg (2002) menyatakan bahwa agresi lebih umum pada remaja laki-laki dibandingkan pada remaja putri dan seringkali berhubungan dengan gangguan emosi seperti perasaan cemas dan depresi. Agresi bisa bersifat defensif (tidakan agresi bertujua untuk mempertahankan diri dari serangan orang 
lan), agresi instrumental (untuk memilii atau menguasai sesuatu obyek atau wilayah), dan emosional (bertujuan mengancam, membahayakan, menyerang orang lain). Perilaku agresi dapat diekspresikan secara verbal maupun fisik.

Banyak ahli setuju bahwa perilaku agresi lebih menggejala pada periode remaja dibandingkan dengan periode lainnya (periode anak atau dewasa). Perilaku agresi yang dilakukan oleh remaja merupakan salah satu bentuk dari tindak kenakalan. Namun demikian, ini tidak berarti bahwa agresi pada periode remaja bukan merupakan suatu gejala yang normatif. Artinya, tindakan agresi bukan merupakan konsekuensi langsung dari perubahan-perubahan yang terjadi pada periode remaja. Remaja yang melakukan agresi tergolong menyimpang. Bahkan tindakan kenakalan itu sendiri juga bukan merupakan suatu bagian dari perkembangan. Jika kenakalan - termasuk di dalamnya tindakan agresi - merupakan bagian dari perkembangan, tentu semua remaja dari berbagai kelompok pupulasi dan budaya akan melakukan tindak kenakalan. Faktanya, tak semua remaja terlibat dalam tindak kenakalan dan dapat melewati masa remaja tanpa melakukan tindakan-tindakan yang merugikan dirinya sendiri maupun lingkungannya. Jadi teori William Stern - teori kelebihan hormon (hormon ragging) - yang menyatakan bahwa adalah wajar bagai remaja melakukan berbagai tindak kenakalan (melanggar hukum) karena mereka kelebihan energi karena melimpahnya produksi hormon dan tindak kenakalan merupakan bagian dari penyaluran energi tersebut - yang awalnya populer, sekarang ini tidak bisa diterima.

Lalu, apa yang menyebabkan banyak remaja melakukan tindakan agresi? Untuk memperoleh jawaban ilmiah tentang pertanyaan ini, dapat digunakan dua model penalaran, yakni induktif dan deduktif. Melalui penalaran induktif kita perlu mengumpulkan bukti-bukti dilapangan kemudian menarik kesimpulan dan membangun teori. Melalui penalaran deduktif kita dapat membuat penjelasan suatu gejala dengan menggunakan teoriteori yang sudah ada. Teori ini kita gunakan sebagai kerangka berpikir atau sebagai paradigma (cara memandang) sesuatu (Kuhn, 2005), misalnya memandang gejala agresi. Dalam bidang intervensi psikologis, penggunaan teori atau paradigma dalam penalaran deduktif bukan hanya bermanfaat untuk memperoleh penjelasan suatu gejala tetapi juga untuk merancang program intervensi guna mengubah gejala tersebut. Berikut adalah beberapa contoh teori yang menjelaskan tentang perilak agresi.

Menurut teori psikodinamika (Nicolson dan Ayers, 2004), semua bentuk perilaku dikendalikan oleh dorongan bawah sadar (tak disadari). Ketika lahir, manusia memiliki dua buah dorongan bawah sadar, yakni instink hidup dan instink mati. Setiap dorongan menunut untuk dipuaskan dan jika mengalami hambatan orang akan mngalami ketegangan, da setiap orang cendrung ing menghindari ketegangan yang dirasakan sebagai suatu keadaan tak menyenangkan. Perilaku agresi dikendalikan oleh instink mati. Dalam proses perkembangannya manusia membentuk kendali diri (ego) dan nilai moral atau kata hati (super ego). Ketiganya disebut sebagai tiga aspek struktur kepribadian. Ego berfungsi mengontrol dorongan-dorongan, termasuk mengarahkan dorongan agresi pada saluran-saluran (aktivitas) yang lebih dapat diterima secara sosial (sesuai standar moral dalam super ego). Pengalaman penolakan, penghindaran, kekerasan atau tekanan yang dialami oleh individu pada masa anak dapat memberikan pengaruh negatif pada kendali diri dan adaptasi terhadap norma sosial. Remaja yang bertindak secara agresif mungkin sebagai upaya untuk melindungi dirnya dari penderitaan (tekanan) psikologis yang muncul dari konflik-konflik yang tak disadari. Mereka 
bertindak agresif sebagai suatu cara atau strategi menangani perasaan-perasaan negatifnya. Perilaku agresif ini pada gilirannya membangkitkan atau memicu respon negatif yang semakin memperburuk perasaan tak menyenangkan yang dialami. Mereka kemudian merasionalisasikan perilakunya, meyakinkan bahwa tindakannya masuk akal dan tak menyimpang dari norma sosial. Agresi dapat juga dipandang sebagai suatu hasil hubungan/ikatan yang tidak aman, dan sebagi akibatnya, remaja tak berkembang menjadi orang dewasa dengan model hubungan yang penuh kepercayaan.

Menurut teori perilaku (Dayakisni \& Hudaniah, 2009; Myers, 2010; Nicolson dan Ayers, 2004) - sering juga disebut teori belajar - remaja melakukan tindakan agresi karena mereka telah dibelajarkan untuk melakukannya. Pembelajaran ini berlangsung melalui mekanisme pembiasaan dan pemodelan. Ada dua mekanisme pembiasaan, yakni pembiasaan klasik yang berkaar pada teori Pavlov dan pembiasaan operan yang berakar pada teori Skinner. Dalam pembiasaan Pavlov, remaja melakukan tindakan agresi sebagai suatu bentuk respon terhadap suatu stimuli. Stimuli ini bisa berupa obyek, peristiwa, atau apa saja yang berpotensi memicu tindakan agresi. Sebagai contoh, remaja mungkin melakukan tindakan agresi karena dimarahi, disakiti, dibuat frustrasi, atau melihat sesuatu yang membuat emosinya meninggi dan ia tak bisa mengontrolnya. Sedangkan menurut teori pengkondisian operan Skinner, remaja bertindak agresi karena ia tidak pernah atau jarang memperoleh konsekuensi yang tepat dari tindakan-tindakan agresi yang dilakukan sebelumnya. Konsekuensi ini adalah suatu peristiwa lingkungan yang terjadi mengikuti tindakan agresi yang bisa berupa penguatan atau hukuman. Anak yang melakukan tindakan agresi dan dapat memperoleh apa yang ia inginkan atau tak memperoleh sanksi hukuman dari lingkungan, akan cenderung mempertahankan perilaku agresinya ketika ia menjadi remaja bahka dewasa. Perilaku agresi akan digunakan sebagai alat untuk memuaskan kebutuhan atau memperoleh apa yang diinginkan.

Tindak kekerasan atau agresi juga bisa dipelajari melalui model. Dalam teori belajar sosial dari Bandura (Corey, 2004; Myers, 2010; Nicolson dan Ayers, 2004), dikatakan bahwa individu bisa mempelajari perilau dengan cara mengamati perilaku orang lain. Jadi, remaja bisa bertindak agresif jika ia sering melihat atau diekspos dengan model perilaku agresif. Model perilaku agresi ini dapat bersifat langsung (anak melihat orang tua, teman, atau orang lain yang berindak agresif dan memperoleh apa yang diinginkan bahkan kekuasaan), simbolik (anak melihat contoh perilaku agresi melalui film, TV, buku, dan majalah), atau imajeri (dengan membayangkan). Jadi, menurut teori perilaku, remaja dapat membentuk pola perilaku agresif dengan beberapa cara berikut: (1) bertindak agresif sebagai respon terhadap stimuli yang memancing tindakan agresi (diejek, diserang, disakiti, dikecewakan, terancam); (2) mengatribusikan tindakan agresifnya dengan kesalahan orang lain, atau mengklaim bahwa orang lain layak menerima tindakan agresif; (3) bertindak agresif dan tak menerima hukuman atau sebaliknya malah menerima reward atau pengauatan dari perilaku agresifnya; (4) menerima hukuman tapi melihat hukuman itu sebagai alat untik mengendalikan orang lain atau memperoleh sesuatu dari orang lain; (5) mengamati model agresif, misalnya orang tua, teman, atau orang lain baik secara langsung maupun tak langsung (simbolik), misalnya melalui gambar atau tayangan di TV; (6) meniru orang lain yang memperoleh sesuatu yang diinginkan atau hadiah dari perilaku agresifnya.

Dari kognitif (Myers, 2010; Nicolson dan Ayers, 2004), diperoleh penjelasan bahwa perilaku agresi dipengaruhi oleh cara anak dan remaja mempersepsi dan 
memahami perilakunya dan oleh karena itu tindakan agresif tergantung pada perkembangan kognitif, khususnya penilaian kognitif. Remaja yang bertindak agresif seringkali gagal untuk mendeteksi pola-pola perilaku positif atau negatif dan mereka seringkali membuat penilaian secara bias dan menempatkan kesalahan pada orang lain bagi tindakan agresinya.

Agresi juga berhubungan dengan rendahnya keterampilan atau kompetensi sosial (Nicolson dan Ayers, 2004). Ketrampilan sosial merupakan aspek penting guna membangun perilaku sosial positif atau interaksi interpersonal yang efektif. Banyak ahli telah menyebutkan, demikian pun banyak hasil penelitian telah memberikan bukti empiris, bahwa rendahnya keterampian sosial dapat menjadi sumber krusial yang memicu tindak kekerasan. Keterampilan sosial memiliki nilai terapeutik untuk mencegah kekerasan dan sebaliknya, mendorong kedamaian. Para ahli psikologi sekolah yang tergabung dalam asosiasi nasional psikolog sekolah di Amerika (2002), telah mengakui bahwa keterampilan sosial merupakan salah satu faktor individu yang mempengaruhi keberhasilan hidup karena ia dapat berfungsi membantu individu memahami dan menyesuaikan diri dengan berbagai lingkungan sosial, mengetahui apa yang harus dikatakan, bagaimana membuat keputusan yang baik, dan bagaimana bertindak secara tepat dalam berbagai situasi (Steedly, et all., 2008). Siswa yang memiliki keterampilan sosial tinggi akan lebih mampu untuk membuat pilihan sosial yang lebih baik, meningkatkan hubungan interpersonalnya, meningatkan keterlibatannya dalam kegiatan ekstrakurikuler, dan memfasilitasi keberhasilannya di sekolah.

\footnotetext{
Program Pelatihan Pengembangan Kemampuan Perspective Taking Sebagai Upaya Mencegah Tindak Kekerasan dan Tawuran Pelajar Remaja
}

Meskipun berbagai tindakan kekerasan dan tawuran (agresi anti sosial) dapat dijelaskan dengan menggunakan berbagai teori, seperti telah dikemukakan pada bagian awal, tulisan ini hanya akan mengemukakan suatu solusi dari pendekatan perkembangan. Pendekatan perkembangan mengajukan formulasi klinis bahwa untuk mendorong perkembangan (menangani perilaku menyimang) maka program intervensi perlu diarahkan pada upaya memodifikasi faktor-faktor yang menghambat perkembangan (mempengaruhi perilaku menyimpang). Suatu gangguan perilaku bisa terbentkuk karena adanya hambatan dalam perkembangan aspek fisik, kognitif, dan sosial. Dalam konteks ini akan lebih menekankan pada hambatan kognitif.

Banyak pendapat yang menyatakan dan hasil penelitian yang membuktikan bahwa berbagai bentuk gangguan perilaku - termasuk di dalamnya tindak kekerasan bersumber pada rendahnya kemampuan kognitif. Kemampuan ini berhubungan dengan cara-cara individu mempersepsi atau memahami orang lain dalam suatu situasi hubungan atau interaksi sosialinterpersonal. Jika individu dapat memahami orang lain - dalam arti perasaan, pikiran, dan tindakannya - maka ia akan lebih dapat mengendalikan emosinya dan dapat bertindak dalam cara yang tidak merugikan orang lain. Tindak kekerasan dan tawuran terjadi karena masing-masing pihak melihat atau memahami sesuatu obyek atau peristiwa secara berbeda. Perbedaan dalam memahami suatu obyek atau peristiwa ini terjadi karena orang menggunakan cara pandang atau perspektif yang berbeda. Perbedaan cara pandang atau persepsi ini disebabkan oleh karena orang memiliki nilai, pengalaman, dan infomasi yang berbeda. Nah jika setiap orang memiliki kemamluan untuk mengakui dan menerima bahwa setiap orang bisa memiliki cara pandang yang berbeda terhadap sesuatu yang sama, maka tindak kekerasan dan 
tawuran akan bisa dihindari, sebaliknya perilaku sosial positif akan berkembang.

Dalam psikologi, konsep yang berkaitan dengan kemampuan untuk menerima dan menghargai cara pandang orang lain disebut dengan kemampuan mengambil perspektif orang lain (social perspective taking, disingkat SPT). Konsep ini berakar pada teori Robert S. Selman yang disebut teori perspective taking yang juga dikenal dengan teori interpersonal understanding. Teori ini dikembangkan oleh Selman pertama kali pada tahun 1980 berdasarkan teori perkembangan kognitif Jean Piaget dan teori perkembangan moral dari Lawrence Kohlberg. Teori ini dikelompokkan ke dalam teori interpersonal yang bersifat perkembangan (developmental in nature) atau pendekatan perkembangan (developmental approach). Menurut teori ini, tindak kekerasan disebabkan karena rendahnya pemahaman interpersonal. Pemahaman interpersonal didefinisikan sebagai suatu kemampuan untuk memahami situasi sosial dalam arti perspektif jamak dari individu-individu yang terlibat. Jadi pemahaman interpersonal ditentukan oleh kemampuan individu untuk mengambil perspektif orang lain dalam suatu situasi sosial (Karcher \& Lewis, 2002). Kemampuan SPT akan mempengaruhi kesadaran individu tentang dampak sosial dari perbuatannya. Dalam teori ini dijelaskan bahwa gangguan perilaku terjadi karena adanya defisit dalam perkembangan kognitif, dan perkembangan kognitif ini mempengaruhi pemahaman interpersonal dan $S P T$. Individu dengan kemampuan SPT tinggi cenderung kurang mungkin terlibat dalam berbagai tindakan kenakalan, agresi, dan kekerasan (Karcher \& Lewis, 2002). Remaja yang mengalami gangguan emosional, terlibat dalam berbagai tindakan agresi, dan menarik diri seringkali memperlihatkan kesenjangan yang lebar antara kemampuan SPT dan strategi negosiasi dalam memecahkan konflik atau masalah interpersonal (Beardslee, Schultz,
\& Selman, 1987; Leadbeater, et all. 1989; dalam dalam Karcher, 2002).

Memperhatikan bahwa kemampuan SPT mempengaruhi keberhasilan (dan kegagalan) dalam interaksi sosial, maka beberapa ahli mengakui kemampuan ini sebagai salah satu bentuk kompetensi sosial. Sebagai contoh Steedly, et all. (2008) menegaskan bahwa kemampuan SPT merupakan salah satu keterampilan sosial yang telah mendapatkan banyak perhatian dari para ahli karena potensinya untuk mencegah konflik dan mendorong empati dan perilaku prososial. Hubungan antara PT dengan kompetensi sosial antara lain dapat dicermati dari pernyataanpernyataan berikut. Misalnya Pronin, Puccio, \& Ross (2002) yang dikemukakan kembali oleh Epley, Morewedge, dan Keysar (2004: 760) memberikan pernyataan berikut,

"Successful social interaction often requires an understanding that others may not interpret the world exactly we as we do. Differeing motivations, expectations, knowedge, or even visual perspective can lead people to interpret the same event very differently, and a failure to recognize these differences can lead to miscommunications".

Penulis lain, Galinsky, $\mathrm{Ku}, \&$ Wang (2005) memberikan penjelasan yang lebih memadai dengan menyatakan sebaga berikut,

"What behaviors, social strategies, and cognitive processes are available to aid in the pursuit of social bond? We proposes that one simple yet vital strategy for smoothing the cogs of social interaction and building social bonds is perspective taking. ...cognitive consequences of perspective taking are a critical mechanism behind its ability to facilitate social coordination and foster social bonds (h.110).,"

".... perspective- taking, having long been recognized as critical to proper social functioning, is a key ingredient in the reduction of interprsonal conflict 
and the construction, manintenance, and preservation of social bonds. From cognitive functioning (Piaget, 1932) to moral reasoning (Kohlberg, 1976), the ability to entertain different perspectives is a crucial mechanism of successful development and is oftentimes considered the foundation of human social capacity (h.111)."

Galinsky, $\mathrm{Ku}, \&$ Wang juga mengemukakan temuan penelitian Davis (1983) yang membuktikan bahwa PT berkorelasi positif dengan kompetensi sosial. Dalam penelitiannya itu Davis juga membuat simpulan bahwa PT akan memfasilitasi pemenuhan kebutuhan untuk memiliki dan untuk membentuk ikatan sosial dengan orang lain di samping meningkatkan a sense of psychological closeness.

Sejumlah negara telah mengembangkan program-program pelatihan keterampilan sosial guna mencegah atau menghentikan tindak kekerasan yang melibatkan remaja. Program ini didasarkan pada hasil-hasil penelitian terdahulu yang membuktikan bahwa tindak kekerasan seringkali berhubungan secara negatif dengan keterampilan sosial (Clayton, Vill, \& Hunsaker, 2001). Ini mengimplikasikan bahwa program pencegahan atau penghentian tindak kekerasan dapat dilakukan dengan mengembangkan keterampilan sosial. Remaja dengan keterampilan sosial tinggi cenderung kurang terlibat dalam tindak kekerasan dan sebaliknya.

Meskipun telah banyak program pelatihan keterampilan sosial dilaksanakan, keefektfan dari program-program tersebut bervariasi tergantung dari cara bagaimana program tersebut dirancang atau dikembangkan. Clayton, Vill, \& Hunsaker (2001) mereviu beratus-ratus bahkan ribuan artikel hasil penelitian tentang program pelatihan keterampilan sosial guna mencegah tindak kekerasan, dan menemukan 30 program yang telah memperlihatkan bukti keefektifannya secara empiris. Dari 30 program kemudian dikelompokkan ke dalam tiga kategori besar, yakni: program anti kekerasan (antiviolence), pemecahan masalah (conflict resolution), dan penciptaan perdamaian (creating peace). Program anti kekerasan menunjuk pada upaya menciptakan suatu iklim lingkungan yang kondusif yang tidak memicu (memprovokasi) tindakan agresi dan kekerasan. Program ini umumnya dilakukan dengan mengembangkan norma perilaku (misalnya aturan kelompok atau norma pergaulan) dan mengajarkan keterampilan kognitif atau bentuk perilaku tertentu (misalnya pengelolaan emosi marah) guna membentuk lingkungan yang bisa menghambat munculnya perilaku agresi dan tindak kekerasan. Program ini efektif untuk menurunkan kekerasan namun belum memberi dampak pada kedamaian lingkungan.

Program yang kedua adalah resolusi konflik. Program ini menunjuk pada upaya menangani konflik-konflik interpersonal sehingga emosi marah dan kesalahpahaman tidak meningkat menjadi tindakan agresi dan kekerasan. Program ini membelajarkan langah-langkah dalam memecahan masalah atau konflik dalam cara yang efektif (tidak memicu kekerasan). Dengan kata lain, program ini memandang keterampilan memecahkan masalah sebagai keterampilan sosial yang harus diajarkan dan dipraktekkan. Program ini lebih baik dibandingkan program yang pertama (program antikekerasan).

Program ketiga adalah penciptaan perdamaian. Program ini dapat melibatkan dua varian program yang lain, namun lebih cenderung memusatkan perhatian pada pengembangan penghargaan (pencitraan) diri dan hubungan dengan orang lain. Pengembangan pencitraan diri dan hubungan dengan orang lain tidak hanya mencegah kekerasan dan menurunkan konflik, tetapi juga menjamin interaksi penuh damai. Dalam konsep ini, 
perdamaian bukan hanya sekedar tiadanya konflik atau kekerasan, namun ia mencakup pengakuan yang mendalam tentang perlunya memberi respek terhadap diri sendiri dan orang lain, dengan diiringi oleh nilai, emosi, dan tujuan yang terarah pada pembentukan perilaku damai secara proaktif. Jadi, tujuan program ini adalah membelajarkan/membentuk perilaku altruis dan pengorbanan diri berdasarkan rujukan (referensi) diri dan orang lain dan disertai perasaan cintakasih. Ciri lain dari program ini adalah sifatnya yang proaktif dan mengajarkan individu tentang bagaimana seharusnya berhubungan dengan semua orang lain secara damai dan merespon konflik dengan cara yang kreatif tanpa kekerasan.

Dari ketiga program terebut, program ke tiga ini diakui sebagai yang paling efektif dibandingkan dengan dua program yang lain. Itu karena program ketiga bukan hanya menghentikan kekerasan tetapi juga menciptakan perdamaian. Dikemukakan oleh Clayton, Vill, \& Hunsaker (2001) bahwa berbagai kualitas perilaku yang disebutkan dalam program ketiga ini berkaitan dengan suatu konstruk psikologis yang disebut perspective taking. fakta ini memperkuat gagasan bahwa pengembangan kemampuan SPT dapat dijadikan sebagai metode guna mencegah dan/atau menghentikan tindak kekerasan sekaligus mendorong perdamaian pada generasi muda.

Sejumlah hasil penelitian juga telah membuktikan bahwa kemampuan SPT meningkatkan kepedulian empati (O'Brien, Konrath, dan Gruhn, 2010), menurunkan stereotipe negatif (Weyant, 2007), menjembatani hubungan antara penolakan sosial dan altruise (Zheng Li, 2011), meningkatkan motivasi menolong (Maner, et all.,2002), menangani hambatan motivasi-onal (Trotchell et all., 2011), meningkatkan keterampilan berteman, hubungan inter-personal, dan perilaku positif di kalangan remaja agresif dan menarik diri (Harton, 2008), memperkembangkan ikatan sosial dan koordinasi sosial (Galinsky, Ku, \& Wang, 2005). Galinsky, Ku, \& Wang sendiri menyatakan bahwa SPT dapat berfungsi sebagai suatu strategi untuk membangun keterikatan sosial dan berfungsi sebagai perekat dalam interaksi sosial. Ini didasarkan pada suatu pemikiran bahwa setiap manusia memiliki kebutuhan untuk diterima, dihargai, direspek oleh dan bergabung dengan orang lain, dan SPT dapat memenuhi kebutuhan itu. Mereka juga mengatakan bahwa PT dapat meningkatkan perilaku stereotip diri dan menurunkan perilaku stereotipe orang lain. Masih banyak penelitian-penelitian lain yang memberikan bukti-bukti tentang pengaruh positif kemampuan SPT pada peningkatan kualitas hubungan sosialinterpersonal. Jika dirangkumkan, semuanya itu menyatakan bahwa derajad kemampuan $P T$ dapat menjadi faktor yang dapat mencegah dan menghentikan kognisi dan motivasi untuk melakukan tindakantindakan kekerasan.

Secara konseptual potensi SPT dalam mempengaruhi kualitas perilaku sosial antara lain dapat disimak dari definisi tentang SPT itu sendiri. Galinsky, $\mathrm{Ku}$, \& Wang (2005: 110) menefinisikan SPT sebagai “... a process of imagining the world from another's vantage point or imagining oneself in another's shoes." Jadi SPT sebagai suatu proses membayangkan dunia dari sudut pandang orang lain atau membayangkan diri kita di dalam sepatu orang lain (mungkin maksudnya berusaha menjadi orang lain secara kognitif dan emosional). Selman (1980), ahli yang mengusulkan konstruk SPT, mendefinisikan SPT sebagai suatu kemampuan manusia yang fundamental untuk memahami pikiran, kebutuhan, keyakinan orang lain; suatu kemampuan to stand in another shoes, dan mengimplikasikan adanya pemahaman interpersonal yang dapat digunakan oleh individu untuk membimbing perilakunya (dalam Karcher, 2002:123). Suatu definisi 
yang agak spesifik diberikan oleh Caruso (2008) dan Epley, Caruso, \& Baseman (2006). Keduanya mendefinisikan SPT sebagai kemampuan untuk memahami dan menerima perbedaan pendapat/pikiran, perasaan, dan tindakan orang lain dalam melihat, menginterpretasi, dan merespon situasi atau obyek yang sama. Jadi, intinya SPT itu merupakan suatu kemampuan untuk memahami bahwa orang lain bisa memiliki pandangan yang berbeda terhadap suatu obyek yang sama, dan kemampuan untuk membentuk perilaku (respon) yang mengandung penghargaan dan penerimaan terhadap perbedaan itu. Jadi, PT dapat meniadakan konflik dan perselisihan; sebaliknya ia dapat mendorong sikap positif terhadap orang lain, perilaku prososial, dan tindakan altruis. Pada gilirannya terciptalah perdamaian antar individu.

Epley, Caruso, \& Baseman (2006) juga mendefinsikan SPT secara afektif dan kognitif. Secara afektif, ia menunjuk pada kemampuan untuk menilai (to assess) emosi dan perasaan diri sendiri dan orang lain; sedangkan secara kognitif ia menunjuk pada kemampuan untuk menilai pikiran, keyakinan, pengetahuan, dan tujuan dari diri sendiri dan orang lain. Namun banyak ahli lain yang menyatakan bahwa SPT merupakan komponen afektif dari empati. Dalam hal ini empati dipandang sebagai suatu konstruk psiklologis yang memiliki komponen kognitif dan afektif. Misalnya Egan (2007) mengemukakan dua komponen empati, yakni: empati emosional (emotionally emphaty), yakni kemampuan untuk dipengaruhi secara emosional oleh kondisi orang lain. Sebagai contoh, saya menjadi sedih ketika melihat orang lain begitu sedih atau menderita. Komponen kognitif, Egan menyebutnya sebagai role-taking emphaty - role taking adalah istilah lain dari perspective taking - adalah kemampuan untuk memahami orang lain dalam arti kondisi, kerangka acuan, atau sudut pandangnya. Jad empati adalah suatu kemampuan keterampilan komunikasi, yakni kemampuan untuk mengkomunikasikan perasaan dan pemahaman yang bersumber dari SPT. Egan (2007) menegaskan bahwa empati merupakan keterampilan yang dapat dipelajari dan dibelajarkan.

Banyak pendapat dan hasil-hasil penelitian telah membuktikan bahwa empati merupakan aspek komunikasi interpersonal yang mampu mempengaruhi kualitas hubungan interpersonal atau interaksi sosial baik dalam seting umum maupun klinis. Kemampuan empati yang tinggi memungkinkan orang tidak hanya bisa memahami keyakinan, sikap, persepsi, dan pandangan-pandangan orang lain tentang peristiwa-peristiwa dan emosi yang dialami mengkuti keyakinan atau pandangan-pandangannya itu, tetapi juga menyebabkan orng lain merasa dimengerti, diterima, dan dihargai. Berdasarkan pengertiannya itu maka orang yang memiliki empati tinggi cenderung bisa menerima dan menghargai orang lain serta tidak melakukan tindakan-tindakan fisik maupun verbal yang dapat menyakiti atau merugikan orang lain. Demikia pula sebaliknya, orang yang merasa diterima dan dihargai cenderung membangun keterikatan yang kuat dengan orang yang mengkomunikasikan empati terhadap dirinya.

Potensi SPT dalam meningkatkan periaku sosial positif dan menurunkan perilaku sosial negatif juga dapat dikaji dari peran SPT dalam strategi negosiasi. Strategi negosiasi adalah suatu ara yang digunakan olehb seseorang dalam menangani konflik dalam hubungan interpersonal. Banyak ahli berpendapat bahwa strategi ini berkorelasi dengan perkembangan kemampuan SPT. Semakin tinggi kemampuan SPT, semakin efektif strategi yang digunakan. Dalam hal ini banyak ahli telah sepakat bahwa kemampuan SPT - seperti halnya kemampuan empati - merupakan kemampuan yang bukan bersifat bawaan 
tetapi kemampuan yang dapat dipelajari dan dikembangkan. Kemampuan ini berkembang melalui lima tahapan dan perkembangan itu dimulai ketika anak berusia tiga tahun dan mencapai tingkat matang ketika anak mencapai usia remaja. Tabel 1 berikut menggambarkan tahapantahapan perkembangan SPT seperti dikemukakan dalam teori Selman.

Tabel 1. Tahapan Perkembangan Kemampuan Perspective Taking

\begin{tabular}{|c|c|}
\hline Tahapan & Deskripsi \\
\hline $\begin{array}{l}\text { Tingkat } 0 \text { : } \\
(3-6 \text { th): } \\
\text { Pandangan } \\
\text { anak } \\
\text { bersifat } \\
\text { egosentris }\end{array}$ & $\begin{array}{l}\text { Anak mengakui bahwa orang lain } \\
\text { bisa memiliki pikiran dan perasaan } \\
\text { yang berbeda dengan dirinya dalam } \\
\text { melihat suatu hal, tetapi mereka } \\
\text { seringkali mengalami kebingungan } \\
\text { dengan hal itu. }\end{array}$ \\
\hline $\begin{array}{l}\text { Tingkat } 1 \\
\text { (6-8 th.): } \\
\text { Perspektif } \\
\text { satu pihak }\end{array}$ & $\begin{array}{l}\text { Anak memahami bahwa terjadinya } \\
\text { perbedaan perspektif antara dirinya } \\
\text { dan orang lain dalam melihat hal } \\
\text { yang sama disebabkan oleh karena } \\
\text { setiap orang memiliki sumber } \\
\text { informasi yang berbeda }\end{array}$ \\
\hline $\begin{array}{l}\text { Tingkat } 2 \\
\text { (8-10 th.): } \\
\text { Perspektif } \\
\text { dua pihak }\end{array}$ & $\begin{array}{l}\text { Anak dapat melangkah masuk ke } \\
\text { dalam pikiran orang lain ("step in } \\
\text { another person's shoes") dan } \\
\text { memandang pikiran, perasaan, dan } \\
\text { perilakunya dari perspektif orang } \\
\text { lain. Mereka juga mengakui bahwa } \\
\text { orang lain dapat melakukan hal } \\
\text { yang sama. }\end{array}$ \\
\hline $\begin{array}{l}\text { Tingkat } 3 \\
10-12 \text { th.): } \\
\text { Perspektif } \\
\text { pihak } \\
\text { ketiga }\end{array}$ & $\begin{array}{l}\text { Anak dapat melangkah keluar dari } \\
\text { situasi dua pribadi dan } \\
\text { membayangkan bagamana dirinya } \\
\text { dan diri orang lain dipandang dari } \\
\text { sudut pandang pihak ketiga. }\end{array}$ \\
\hline $\begin{array}{l}\text { Tingkat } 4 \\
(12-15 \text { th. } \\
\text { ke atas.): } \\
\text { perspektif } \\
\text { taking } \\
\text { sosial } \\
\text { (SPT) }\end{array}$ & $\begin{array}{l}\text { Individu memahami bahwa } \\
\text { perspektif pihak ke tiga dapat } \\
\text { dipengaruhi oleh satu atau lebih } \\
\text { sistem nilai masyarakat yang lebih } \\
\text { luas. }\end{array}$ \\
\hline
\end{tabular}

Teori Selman tentang model perkembangan SPT tersebut banyak dijadikan rujukan oleh penulis-penulis lain dalam bidang teori dan penelitian SPT. Selman sesungguhnya mengembangkan modelnya tersebut berdasarkan teori perkembangan kognitif dari jan Piaget dan teori perkembangan Moral dari Lawrence Kohlberg ditambah dengan hasil penelitiannya. Untuk melihat perkembangan PT dari tahap ke tahap, Selman membacakan suatu ceritera kepada subyek dari setiap tahapan kelompok usia dan kemudian mengajukan pertanyaan. Ceritera tersebut berkaitan dengan seorang anak (Holly), sebagai berikut:

"Holly adalah seorang anak perempuan yang berusia delapan tahun yang gemar sekalai memanjat pohon, bahkan ia terkenal sebagai pemanjat pohon terbaik di lingkungan tempat tinggalnya. Pada suatu hari ayahnya melihat Holly jatu dari pohon yang dipanjatnya. Meskipun Holly tidak mengalami cedera yang berarti, ayahnya sangat cemas dan memaksa Holly berjanji bahwa ia tidak akan memanjat pohon lagi $d$, dan Holly memenuhinya."

Pada suatu hari, Holly ketemu Togop yang memberitahukan bahwa anak kucing peliharaan Amir terjebak di atas pohon an tak bisa turun. Harus ada yang mau memanjat pohon untuk menyelematkan anak kucing tersebut, dan Holly adalah satu-satunya anak yang bisa memanjat pohon dan menyelematkan anak kucing tersebut. Namun Holly ragu-ragu untuk melakukannya karena ia teringat janjinya pada ayahnya.

Anak dari usia yang berbeda memberikan jawaban yang berbeda. Namun sebenarnya perbedaan jawaban ini tidak bersumber pada usianya, namun lebih pada tahapan perkembangan kognitif yang terjadi mengikuti usia tersebut. Dalam perkembangan normal, dari usia anak hingga remaja, pertabahan usia akan diikuti pertambahan perkembangan kognitif. Berikut adalah jawaban yang diperoleh oleh Selman dari anak-anak dari kelompok usia berbeda.

\section{Tahap egosentris (tahap 0):}

Holly tentu akan menyelamatkan anak kucing karena ia tidak ingin anak kucing tersebut celaka, dan ayah Holly tentunya akan merasa senang dengan apa yang dilakukan oleh Holly karena ia tentu juga menyukai anak kucing.

Perspektif satu pihak (tahap 1): 
Ketika ditanya bagaimana reaksi ayah Holly ketika ia melihat anaknya memanjat pohon, anak memberikan jawaban berikut: "jika ia tidak tahu sesuatu tentang anak kucing, ia akan marah. Tetapi jika Holly memperlihatkan anak kucing itu pada ayahnya, tentu ayahnya akan berubah pikiran dan tidak marah.”

\section{Perspektif dua pihak:}

Ketika ditanyakan apakah Holly berpikir ia akan dihukum oleh ayahnya, anak menjawab: "Tidak. Holly tahu ayahnya akan mengerti mengapa ia memanjat pohon." Respon ini didasarkan pada asumsi bahwa sudut pandang Holly dipengaruhi oleh kemampuan ayahnya untuk mengambil perspektif Holly dan memahami mengapa Holly menyelamatkan anak kucing.

\section{Perspektif pihak ketiga:}

Ketika ditanyakan apakah Holly harus dihukum jika ia memanjat pohon, anak menjawab: "Tidak, karena Holly berpikir bahwa anak kucing tersebut harus diselamatkan. Jadi Holly berpikir bahwa ia seharusnya tidak dihukum karena ia memiliki alasan yang baik (melakukan hal yang baik berupa menyelamatkan anak kucing)."

\section{Perspektif taking sosial (SPT):}

Ketika, kepada subyek ditanyakan apakah Holly harus dihukum, mereka menjawab: "Tidak. Nilai kemanusiaan yang mendorong tindakan menyelamatkan anak kucing yang akan mempertimbangkan tindakan Holly. Apresiasi ayah Holly terhadap nilai kemanusiaan ini akan membuatnya tidak menghukum Holly."

Selman (1980, dalam Karcher, 2002) mengatribusikan setiap tahapan ketrampilan SPT akan mendasari strategi negosiasi yang digunakan oleh anak dalam menangani konflik interpersonal. Strategi ini disebut dengan strategi negosiasi interpersonal, disingkat SNI. Keterampilan SPT akan mendorong pemahaman interpersonal dan pemahaman interpersonal ini menentukan kesadaran individu tentang dampak sosial dari perbuatannya. Kesadaran ini akan menjadi dasar bagi individu untuk menggunakan SNI. SNI memiliki dua kemungkinan arah atau orientasi interpersonal, yakni: self-transforming (ST) dan others transforming (OT). Sebagai contoh, PT egosentris akan mengarahkan individu untuk memperlihatkan pemahaman interpersonal yang tidak matang, seperti ketika mereka melakukan suatu tindak kenakalan dan seakan mengabaikan bahwa masyarakat umumnya menilai tindakan impulsif mereka. Anakanak seperti ini (impulsif) tampak tidak peduli dengan ramifikasi tindakan kenakalan mereka. Namun, anak-anak lain yang telah mampu untuk mengkoordinasikan dua perspektif sosial secara simultan akan menyadari bahwa orang lain memiliki suatu kehidupan psikologis internal yang tak kasat mata dan tak dapat disimpulkan secara obyektif. keadaran ini akan mengarahkan mereka untuk melihat norma-norma sosial guna memprediksikan suatu tindakan tertentu dan dampak dari tindakan itu. Juga dihipotesiskan bahwa bstrategi negosiasi yang dipraktekkan dalam PC akan ditransfer kedalam situasi hubungan yang lain dan hubungan romantik pada periode remaja akhir dan dewasa. Hubungan ini diilustrasikan pada tabel 2 berikut:

Tabel 2. Hubungan antara perkembangan kemampuan SPT dengan penggunaan strategi negosiasi interpersonal (SNI), dan orientasi interpersonal (OI): self-transforming (ST) dan others transforming (OT)

\begin{tabular}{|l|l|l|}
\hline \multirow{2}{*}{$\begin{array}{l}\text { Tahap PPT } \\
\text { Serk. }\end{array}$} & Strategi Negosiasi Interpersonal (SNI) \\
\cline { 2 - 3 } & $\begin{array}{l}\text { Self- } \\
\text { Transforming } \\
(\mathrm{ST})\end{array}$ & $\begin{array}{l}\text { Others-Transforming } \\
\text { (OT) }\end{array}$ \\
\hline $\begin{array}{l}\text { Perspektif } \\
\text { pihak ketiga: } \\
\text { Kolaboratif }\end{array}$ & $\begin{array}{l}\text { Dua belah pihak saling berbagi. } \\
\text { Menekankan kebersamaan dalam } \\
\text { memenuhi kebutuhan dan memecahkan } \\
\text { masalah masalah da membangun perspektif } \\
\text { bersama atau perpektif kita. Di sini setiap }\end{array}$ \\
\hline
\end{tabular}




\begin{tabular}{|l|l|l|}
\hline & $\begin{array}{l}\text { tindakan selalu dinilai dampaknya pada } \\
\text { hubungan }\end{array}$ \\
\hline $\begin{array}{l}\text { Perspektif dua } \\
\text { pihak: saling } \\
\text { mempengaruhi } \\
\text { (resiprokal) }\end{array}$ & $\begin{array}{l}\text { Bertanya, barter, } \\
\text { mengikuti pihak } \\
\text { kedua }\end{array}$ & $\begin{array}{l}\text { Memberikan argumen, } \\
\text { mempersuasi, } \\
\text { mengikuti pihak } \\
\text { pertama }\end{array}$ \\
\hline $\begin{array}{l}\text { Perspektif satu } \\
\text { pihak: }\end{array}$ & $\begin{array}{l}\text { Patuh, } \\
\text { menyerah, } \\
\text { menilateral }\end{array}$ & $\begin{array}{l}\text { Mendikte, menggertak, } \\
\text { mempengaruhi }\end{array}$ \\
\hline $\begin{array}{l}\text { Perspektif } \\
\text { egosentris : } \\
\text { impulsif }\end{array}$ & $\begin{array}{l}\text { Merengek, } \\
\text { bersembunyi, } \\
\text { melarikan diri }\end{array}$ & $\begin{array}{l}\text { Merebut/mengambil, } \\
\text { memukul, berjuang }\end{array}$ \\
\hline
\end{tabular}

Diadaptasi dari Karcher (2002).

Dari tabel tersebut dapat dibaca bahwa pada setiap tahapan perkembangan kemampuan SPT berkaitan dengan SNI. Pada tahap egosentris, individu cenderung menggunakan strategi impulsif yang antara lain dalam bentuk merengek, lari, atau bersembunyi (ST), atau berkelahi, merebut/merampas, atau memukul (OT). Anak yang merengek atau menangis untuk memperoleh persetujuan, atau anak yang lari atau bersembunyi karena telah merusakkan mainan orang lain, atau anggota DPR yang keluar ruangan (walk out) adalah contoh dari SNI-ST. Remaja yang merusak fasilitas umum, mengajak berkelahi atau memukul temannya untuk mendapatkan persetujuan atau apa yang ia inginkan adalah contoh SNI-OT.

Pada tahap 1, perspektif satu pihak, anak menggunakan strategi unilateral. Untuk melakukan negosiasi, mereka bisa menggunakan SNI dengan cara menuruti, memberi atau mengalah (ST) atau menguasai, memerintah, menyakiti (OT). Pada tahap ke 2, perspektif dua pihak, anak menggunakan strategi resiprokal dalam bernegosiasi, yakni dengan cara meminta alasan, barter, atau mengikuti (ST) atau dengan cara sebaliknya, yakni membuat argumentasi, mempengaruhi, atau meleburkan dirinya (OT). Pada tahap ketiga, anak sudah mampu untuk bekerjasama dan menggunakan strategi kolaboratif. Dalam bernegosiasi semua pihak yang terlibat dalam interaksi sudah dapat berbagi kepentingan, menempatkan kepentingan bersama di atas kepentingan individual, dan membangun perspektif bersama (we perspective). Semua tindakan yang akan diambil dipertimbangkan dampaknya pada hubungan, dan hanya tindakan yang menjaga kebersamaan yang akan dipilih untuk dilakukan.

Dari apa yang dikemukakan tentang hubungan antara kemampuan SPT dengan SNI jelas bahwa semakin tinggi kemampuan SPT individu, semakin efektif ia menggunakan SNI. Keefektifan ini ditandai oleh adanya tindakan yang lebih menekan kebersamaan dan menghindari konflik.

\section{Strategi Pengembangan Program}

Dari paparan tentang kemampuan SPT tersebut dapat dimengerti bahwa kemampuan SPT bukan merupakan kemampuan bawaan melainkan kemampuan yang dapat dikembangkan atau dibelajarkan. Ini mengimplikasikan bahwa sekolah dapat mengembangkan program-program intervensi guna mencegah dan menangani berbagai tindak kekerasan dan/atau tawuran di kalangan pelajar. Cara bagaimana program ini dirancang dan dilaksanakan tentu akan bervariasi luas tergantung pada kondisi dan kebijakan yang ada pada setiap lembaga sekolah. Beberapa strategi bisa ditempuh. Program pencegahan dan penanganan tindak kekerasan bisa merupakan kurikulm tersendiri, menjai bagian dari kurikulum pendidikan karakter, terpadu dengan mata pelajaran seperti dalam kurikulum 2013 saat ini, atau menjadi bagian dari program pelayanan bimbingan dan konseling sekolah. Program bisa bersifat preventif (pencegahan) atau kuratif/remedial (penanggulangan). Namun jika program dimaksudkan sebagai apaya preventif maka ia harus diprogramkan secara teratur dan terstruktur. Berikut adalah aspek yang perlu diperhatikan guna memperoleh suatu pro-gram pengembangan PT yang efektif.

1. Tujuan Program

Tujuan umum program adalah menghentikan potensi tindak kekerasan di kalangan pelajar. Sedangkan tujuan khusunya adalah memberikan intervensi 
psikologis untuk menghentikan potensi tindak kekerasan dan tawuran pelajar dengan cara mengembangkan kemampuan SPT

2. Sifat program

Program bisa bersifat preventif (pencegahan) atau kuratif (penyembuhan). Namun program penanggulangan terhadap kekerasan generasi muda sebaiknya diberikan sejak awal, bahkan jika mungkin bisa diberikan sejak usia sekolah dasar. Ini setidaknya didasarkan pada alasan berikut. Pertama, pembentukan keterampilan sosial-interpersonal mulai belangsung ketika anak berada di sekolah dasar. Seperti dikemukakan oleh Dusenbery et., all (1997) dalam Clyton, Bllif-Spanvil, \& Hansaker (2001) bahwa pencegahan tindak kekerasan dan pembentukan perilaku prososial perlu dibelajarkan pada saat keterampilan tersebut berada pada tahap perkembangan. Beberapa keterampilan sosial tertentu, salah satunya keterampilan PT adalah kurang logis jika diajarkan pada anak usia dini karena mereka ini termasuk ke dalam kelompok yang belum matang baik secara intelektual maupun emosional (Duesenberry, at all., 1997). Kedua, tindak kekerasan umumnya memiliki onset perkembangan dari waktu ke waktu; anak usia SD yang senang melakukan tindakan kekerasan cenderung akan memperlihatkan perilaku yang sama ketika mereka menjadi remaja dan orang dewasa (Grossman et all, 1997; dalam Clyton, Bllif-Spanvil, \& Hansaker, 2001). Intervensi yang diberikan pada usia awal dipandang menjadi metode yang lebih tepat guna menghentikan tindak kekerasan. Ketiga, pengaruh orang tua/orang dewasa (dalam bentuk pendidikan) untuk membentuk PT dan keterampilan sosial yang lain kurang efektif jika diberikan pada saat remaja (Howard et., al. 1997, Thornton et al,.
2000). Anak-anak lebih senang mempelajari keterampilan sosial interpersonal (PT) ketika mereka masih anak-anak. Sifat preventif ini tidak hanya dapat mengendalikan tindak kekerasan tetapi juga mendorong kinerja akademik. Seperti dikemukakan oleh Ellickson (1997), pelatihan keterampilan sosial untuk anak dan remaja merupakan suatu strategi yang efektif untuk menangani kegagalan sekolah, kecanduan rokok, mariyuana, dan aktivitas seksual.

3. Struktur Program

Program akan lebih efektif dan efisien jika dilaksanakan di sekolah dan bukan di luar sekolah. Beberapa penelitian telah menyatakan bahwa program pencegahan kekerasan lebih efektif jika didukung oleh perubahan positif dalam lingungan anak (Dusenbury et al., 1997; dalam Clyton, Bllif-Spanvil, \& Hansaker, 2001). Pengembangan perilaku prososial perlu ditunjang (dilaksanakan) di dalam suatu konteks lingkungan yang mendukung. Lingkungan sekolah lebih mendukung dibandingkan lingkungan tempat tinggal. Sebaliknya, lingkungn di luar sekolah bahkan di tempat tinggal banyak mengekspos anak dengan berbagai model tindak kekerasan. Demikian pula sekolah dapat menjadi tempat pelatihan bagi keterampilan sosial maupun arena penerapan keterampilan sosial. Program intervensi ini sebaiknya menjadi bagian dari kurikulum sekolah. Jadi program ini menjadi semacam mata pelajaran yang materinya adalah mengajarkan keterampilan sosial (perspective taking). Fakta yan kita amati saat ini adalah bahwa kurikulum tradisional yang mengintegrasikan pendidikan moral/karakter dengan mata plajaran terbukti tidak mencukupi untuk mencegah kekerasan para siswa. Sebagai alternatif, program ini dapat dimasukkan ke dalam program bimbingan dan konseling sekolah dan 
menjadi materi dalam kurikulum bimbingan.

4. Teknik

Agar efektif maka program tidak hanya dirancang berdasarkan kerangka kerja konseptual yang relevan, tetapi juga menggunaan teknik yang tepat untuk mengimplementasikannya. Dalam hal ini telah tersedia sejumlah teknik intervensi dari berbgai pendekatan dan orientasi teoretik yang dapat digunakan baik secara tunggal maupun kombinatif. Teknik mana yang akan dipilih tentu harus mempertimbangkan beberapa faktor seperti relevansi teknik dengan tujuan dan hasil-hasil penelitian yang telah dilakukan untuk mengiji efikasi dari teknik tersebut. Sebagai contoh, penelitian LeBlanc, Coates, \& Lancaster (2003) telah membuktikan keefektifan teknik video modeling dan reinforcement baik secara sendiri maupun kombinatif untuk membelajarkan kemampuan SPT pada subyek autis yang berusia antara 6-12 tahun. Beberapa penelitian lain juga telah mendukung keefektifan penggunaan teknik pemodelan untuk membelajarkan kemampuan SPT. Teknik bermain peran juga terbukti efektif untuk meningkatkan SPT. Yang perlu diingat adalah bahwa keefektifan dari suatu metode intervensi yang dimaksudkan untuk mengembangkan atau membelajarkan $P T$ dapat bervariasi karena berdasarkan pada hasil penelitian yang sudah dilakukan kemampuan $P T$ dipengaruhi oleh sejumlah faktor seperti budaya (Wu dan Keysar, 2007), usia (Epley \& Morewedge, 2004), gender dan etnis (O'Brien, Konrath, \& Gruhn, 2010), self-esteem (Galinsky \& Ku, 2004), kemampuan kognitif (Lamm, Batson, dan Decety, 2009), kecerdasan atau fungsi intelektual (Gore, BarnessHolmes, \& Murphy, 2010). Konseling bermain (play therapy) juga potensial untuk digunakan sebagai teknik untuk mengembangkan kemampuan SPT khususnya untuk anak-anak usia sekolah dasar yang lebih antusias merespon metode-metode bermain. Beberapa pendapat juga telah menyatakan dampak positif bermain pada perkembangan kemampuan kognitif anak.

\section{SIMPULAN}

Fenomena tindak kekerasan dan tawuran antara pelajar yang cenderung meningkat baik secara kuantitas dan kualitas pada beberapa tahun belakangan ini telah menimbulkan keprihatinan banyak pihak dan mendesak untuk metode penanganan yang lebih efektif. Secara khusus, fenomena tindak kekerasan dan tawuran antar pelajar memiliki implikasi langsung bagi pengembangan programprogram intervensi di sekolah. Merebaknya fenomena tindak kekerasan dan tawuran pelajar saat ini mengindikasikan bahwa program-program intervensi yan telah dilakukan terbukti kurang efektif dan sekola perlu mencari program yang lebih efektif. Pendekatan perkembangan, suatu program yang memberikan intervensi secara tidak langsung guna menghentikan suatu gejala perilaku tak adaptif, yakni dengan melakukan modifikasi terhadap faktorfaktor yang mempengruhi gejala, dapat menjadi strategi intervensi alternatif yang secara teoretik lebih tepat untuk diterapkan pada kaum pelajar yang notabene masih berada pada proses perkembangan. Program pelatihan pengembangan kemampuan SPT dipilih sebagai program pencegahan yang dinilai efektif untuk mencegah dan bahkan menangani tindak kekerasan. Ini didasarkan pada fakta teoretik dan hasil-hasil penelitian terdahulu. Secara teoretik, tindak kekerasan bisa bersumber pada rendahnya kemampuan pemahaman interpersonal, dan kemampuan pemahaman interpersonal ini dipengaruhi oleh keterampilan setiap orang dalam mengambil perspektif orang lain. Jika 
setiap orang dapat mengambil perspektif orang lain, yakni mampu menerima dan menghargai bahwa setiap orang bisa membuat dalam arti apa yang dirasakan, dipikirkan, dan dilakukan, dan kemudian membuat respon antisipatif sesuai dengan pemahamannya itu, maka tindak kekerasan tidak akan terjadi. Atas dasar pemikiran ini maka program-program pencegahan dan penanganan tindak kekerasan di kalangan pelajar dapat dilakukan melalui program pengembangan kemampuan SPT di sekolah. Secara konseptual kmampuan SPT bukan merupakan kemampuan bawaan tetapi kemampuan yang dapat dipelajari atau dibelajarkan. Dengan demikian program pelatihan dapat digunakan sebagai suatu bentuk pembelajaran. Agar efektif maka program harus dirancang berdasarkan strategi tertentu. Strategi ini meliputi pemilihan pendekatan konseptual, teknik, dan sifat program. Beberapa penelitian terdahulu telah membuktikan keefektifan beberapa teknik intervensi seperti pemodelan dan bermain peran untuk melatihkan kemampuan SPT baik diginakan secara sendiri maupun kombinatif. Berkaitan dengan sifat program, program yang bersifat pencegahan lebih ditekankan dibandingkan sifat kuratif. Program ini sebaiknya dilakukan sejak jenjang pendidikan dasar karena beberapa alasan. Pertama bahwa anak yang telah belajar melakukan tindak kekerasan akan melakaukan hal yang sama ketika ia menjadi remaja dan orang dewasa. Kedua, usia anak merupakan wakt yang tepat untuk mengembangkan keterampilan sosial. Sifat lainnya adalah bahwa program perlu menjadi bagian dari kurikulum sekolah atau menjadi bagian dari kurikulum bimbingan dan konseling sekolah.

\section{DAFTAR PUSTAKA}

Clayton, C.J. , Ballif-Spanvill, B., \& Hunsaker, M.D. (2001). Preventing violence and teaching peace: A review of promising and effective antiviolence, conflict resolution, and peace programs for elementary school children. Apllied and Preventive Psychology, 10, pp. 1-35.

Dayakisni, T., \& Hudaniah. (2009). Psikologi Sosial. Edisi revisi. Malang: UMM Press.

Egan, G. (2007). The Skilled Helper. A Systematic Approach to Effective Helping. California: Brooks/Cole Publishing Company.

Epley, N., Morewedge, C.K., \& Keysar, B. (2004). Perspective taking in children and adults: Equivalent egocentrism but differential correction. Journal of Experimental Social Psychology, 40, 760-768.

Epley, N., Caruso, E, M., \& Bazerman (2006). When perspective taking increases taking: Rective egoisme in social interaction. Journal of Peronality and Social psychology, 91, no. 5., 872-889.

Epley, N., \& Caruso, E,M. (2008). Perspektive-taking: Misstepping other's shoes. Handbook of Imagination and mental simulation.

Nicholas Epley, N., Caruso, E.M., \& Bazerman, M.H. (2006). When Perspective Taking Increases Taking: Reactive egoism in Social Interaction. Journal of Personality and Social Psychology, 2006, Vol. 91, No.5, pp. 872-889

Galinsky, A.D., Ku, G., \& Wang, C.S. (2005). Perspektive -Taking and self-other overlap: Fostering social bons and facilitating social coordination. Group Pocess \& Intergroup Relations, 8, 109-124.

Galinsky, A.D., \& Moskowitz, G.B. (2000). Perspective Taking: Decreasing Stereotype Expression, Stereotype Accessibility, and InGroup Favoritsm. Journal of Personality and Social Psychology, 2000, Vol. 78, No. 4, pp. 708-724.

Gore, N.J., Holmes, Y.B., \& Murphy, G. 2010. The Relationship between 
Intellecctual Functioning and Relational Perspective Taking. International Journal of Psychology and Psychological Therapy, 2010, Vol. 10, No. 1, pp. 1-17

Hackney, H.L., \& Cormier, L.S. (2001). The Professional Counselor. A Process Guide to Helping. Boston: Allyn \& Bacon.

Harton, J.K. (2008). Pair Counseling for High School Students: Improving Friendship Skills, Interpersonal Relationship, and Behavior among Aggressive and Withdrawn Adolescence. International Journal of Play Therapy, 2008

Karcher, M.J. (2002). The principles and practice of pair-counseling: a dyadic developmental. Play therapy for agressive, withdrwn, and socially immature youth. International Journal of Play Therapy, 11, 121147.

Karcher, M.J., \& Lewis, S.S. (2002). Paircounseling: The effect of a dyadic evelopmental play therapy on interpersonal understanding and externalizing behaviors.

International Journal of Play Therapy, 11, 19-41.

Komnas-PA (2012). "Menggugat Peran Negara, Pemerintah, Masyarakat, dan Orang Tua dalam Menjaga dan Melindungi Anak" pada sub judul "Kekerasan di Lingkungan Sekolah," Tersedia: www.

Komnaspa.wordpress.com. tanggal 12 Desember 2012.

Kuhn, T.S. (2008). The Structure of Scientific Revolution. Peran Paradigma dalam Revolusi Sains. Cetakan keenam. Bandung: PT Remaja Rosdakarya

LeBlanc, L., Coates, A, M., \& Lancaster, B.M. (2003). Using Video Modeling and Reinforcement to Teach Perspective Taking Skills to Children with Autism. Journal of Applied
Behavioral Analysis, 2003, No. 2, 36,253-257

Lerner, R.M. \& Hultsch, D.F. (1983). Human Development. A Life Span Perspective. New York: McGrawHill Book Comapany.

Mandar, H.A. (2012). "Program Bimbingan Pribadi Berdasarkan Profil Perilaku Agresif Siswa Sekolah menengah Atas" (Skripsi). Universitas Pendidikan Indonesia.

Maner, J.K., Luce, C.L., Neuberg, S.I., Cialdini, R.D., Brown, S., \& Sagarin, B.J. (2002). The Effect of Perspective Taking on Motivations for Helping: Still No Evidence for Altruism. Personality and Social Psychology Bulletin, Vol. 28, No. 11, November, 2002, pp. 1601-1610.

Myers, D.G. (2010). Social Psychology. New York: Mc. Graw Hill.

Nicolson, D., \& Ayers, H. (2004). Adolescent Problems. A Practical Guide For Parents, Teachers And Counsellors. Revised edition. Great Britain: David Fulton Publishers, Ltd.

O’Brien, Konrtah, S.H., Gruhn, D., \& Hagen, A.L. (2010). Empathic Concern and Perspective Taking: Linier anda Quadratic Effects of Sge Across the Adult Life Span. The Journal of Gerontology, Series B: Psychological Sciences and Social Sciences, doi: 10, 1093/geromb/gbs055

Papalia, D.E., \& Olds, S.W. (1995). Human Development. 6th. Ed. New York: McGraw-Hill.

Segrin, C. 2009. "Social Skill Training." Dalam O,Donohue, W.T., \& Fisher, Z.E. (ed). General Principles and Empirically Supported Techniques of Cognitive Behavioral Therapy. New Jersey: John Wiley \& Sons.

Selman, R. L. (1980). The growth of interpersonal understanding: Developmental and clinical analyses. New York: Academic Press. 
Selman, R.L., \& Schultz. L.H. (1990). Making friend in youth: Developmental theory and pairtherapy. Chicago, IL: University of Chicago Press.

Selman, R.L. (2003). The promotion of social awareness: Powerful lesson from the partnership of developmental theory and classroom practice. New York: Russel Sage Foundation.

Schultz, L.H., \& Selman, R.L. (1989).

Bridging the gap between interpersonal thought and action in early adolescence. The role of psychodinamic processes. Development and Psychopathology, 1, 133-152.
Steedley, K.M., Schwartz, A.S., Levin, M., \& Luke, S.D. (2011). Social skills and academic acheveent. Evidence for Education, Vol. III, Issue 2.

Stenberg, L. 2002. Adolescence. Sixt ed. International Edition. Boston: McGraw Hill.

Thompson, C.L., Rudolph, L.B., \& Anderson, D. (2004). Counseling Children. 6th. Ed. Australia: Thompson, Brook/Cole 